Canadian University Music Review

Revue de musique des universités canadiennes

\title{
Origins and Distinctions of the "World Music" and "World Beat" Designations
}

\section{Brad Klump}

Volume 19, numéro 2, 1999

Canadian Perspectives in Ethnomusicology

Perspectives canadiennes en ethnomusicologie

URI : https://id.erudit.org/iderudit/1014442ar

DOI : https://doi.org/10.7202/1014442ar

Aller au sommaire du numéro

Éditeur(s)

Canadian University Music Society / Société de musique des universités canadiennes

ISSN

0710-0353 (imprimé)

2291-2436 (numérique)

Découvrir la revue

Citer cet article

Klump, B. (1999). Origins and Distinctions of the "World Music" and "World Beat" Designations. Canadian University Music Review / Revue de musique des universités canadiennes, 19(2), 5-15. https://doi.org/10.7202/1014442ar

\section{Résumé de l'article}

This article traces the origins and uses of the musical classifications "world music" and "world beat." The term "world beat" was first used by the musician and DJ Dan Del Santo in 1983 for his syncretic hybrids of American R\&B, Afrobeat, and Latin popular styles. In contrast, the term "world music" was coined independently by at least three different groups: European jazz critics (ca. 1963), American ethnomusicologists (1965), and British record companies (1987). Applications range from the musical fusions between jazz and non-Western musics to a marketing category used to sell almost any music outside the Western mainstream.
All Rights Reserved @ Canadian University Music Society / Société de musique des universités canadiennes, 1999
Ce document est protégé par la loi sur le droit d'auteur. L'utilisation des services d'Érudit (y compris la reproduction) est assujettie à sa politique d'utilisation que vous pouvez consulter en ligne.

https://apropos.erudit.org/fr/usagers/politique-dutilisation/ 


\title{
ORIGINS AND DISTINCTIONS OF THE "WORLD MUSIC" AND "WORLD BEAT" DESIGNATIONS
}

\author{
Brad Klump
}

The world was so recent that many things lacked names, and in order to indicate them it was necessary to point. (Gabriel García Márquez ${ }^{1}$ )

I would be happy if what I played would simply be called music, nothing else. (Charlie Parker)

The field of ethnomusicology has applied many labels over the years to reflect the types of music that comprise its area of study. Descriptors such as "savage," "primitive," "non-literate," and "ethnic" have now largely been abandoned, particularly for their ethnocentric connotations. ${ }^{2}$ Ethnomusicologists have not been the only ones grappling with suitable labels for much of the world's vast musical output. People within the record industry have also attempted to define, in a succinct phrase, music from around the globe. Such terms as "international music," "global pop," "tropical music," "global beat," "musique métisse," "international mix," and "ethno-pop" are some that have received limited currency in the media. ${ }^{3}$ However, few labels have generated more controversy, in both academia and the public realm, than the terms "world music" and "world beat." 4

1 Gabriel García Márquez, One Hundred Years of Solitude (London: Picador, 1983), 9.

2Helen Myers, "Ethnomusicology," in Ethnomusicology: An Introduction, ed. Helen Myers (New York: W. W. Norton, 1992), 11.

3Daisann McLane, "The Global Beat," in The Rolling Stone Illustrated History of Rock \& Roll, ed. Anthony DeCurtis, James Henke, and Holly George-Warren (New York: Random House, 1992), 663.

4 See Steven Feld, "From Schizophonia to Schismogenesis: On the Discourses and Commodification Practices of 'World Music' and 'World Beat,'" in Music Grooves: Essays and Dialogues, ed. Steven Feld and Charles Keil (Chicago: University of Chicago Press, 1994), 257-89; Feld, "Notes on 'World Beat,"' in Music Grooves, 238-46; Line Grenier and Jocelyne Guilbault, “'Authority' Revisited: The 'Other' in Anthropology and Popular Music Studies," Ethnomusicology 34, no. 3 (1990): 381-97; Reebee Garofalo, "Whose World, What Beat: The Transnational Music Industry, Identity, and Cultural Imperialism," World of Music 35, no. 2 (1993): 16-32; Rick Glanvill, "World Music Mining: The International Trade in New Music," in Rhythms of the World, ed. Francis Hanly and Tim May (London: BBC Books, 1989), 58-67; Deborah Pacini Hernandez, "A View from the South: Spanish Caribbean Perspectives on World Beat," World of Music 35, no. 2 (1993): 48-69; Maria Jimenez, "World Music Forum," Asymptote 5 (1991): 33-35; McLane, "The Global Beat," 663-71; Tony Mitchell, "World Music and the Popular Music Industry: An Australian View," Ethnomusicology 37, no. 3 (1993): 309-38; Tom Moon, "World Music Forum," Asymptote 5 (1991): 33-35; Myers, "Ethnomusicology"; Alastair Sutherland, "Global Rhythms: The Pop World Moves to an International Beat," Toronto Living Fashion (March 1989): 51, 148; Philip Sweeney, The Virgin Directory of World Music (New York: 
The purpose of this paper is to outline the origins and definitions of the musical designations "world music" and "world beat" in order to shed light on why, in recent years, these two terms have come to mean different things to some groups and the same thing to others. The histories of these terms reflect a certain irony, for though their original meanings carried an intended "inclusive" connotation (related to the removal of cultural, political, and musical barriers), they have since been used to differentiate and "exclude" certain artists, peoples, and musical styles from most European and American musics. Moreover, since one cannot get a clear sense of how the terms have been used over the years without acknowledging the politics of labelling, I will outline a number of critiques pertaining to the "world music" and "world beat" classifications. While the rhetoric surrounding these labels celebrates a "liberatory" agenda, ${ }^{5}$ these critiques explore how recent applications point to a classificatory scheme that fixes and marginalizes certain musical genres and cultural groups, and exemplifies the privileged positioning and power differential between the "categorizers" and the "categorized." What seems to be an innocent need to label certain kinds of music, in essence, becomes a site for constructing an entire social-hierarchical system. ${ }^{6}$

\section{A HISTORY OF THE TERM "WORLD BEAT"}

As far as I am aware, the term "world beat" was first coined by the famous American author, Jack Kerouac, in his 1957 novel, On the Road. ${ }^{7}$ Kerouac's novel was influential for many American youth in the 1950s and 1960s, inspiring their quests for unbounded freedom and spiritual enlightenment. In fact, writers like Kerouac, Allen Ginsberg, William Burroughs, and Gregory Corso (among others) were progenitors of what became known as the "Beat" Generation. ${ }^{8}$

Whether or not there is any connection between Kerouac's use of the term "world beat" and its recurrence almost thirty years later is uncertain. Nonetheless, the phrase was (re)discovered by the Austin, Texas-based musician, composer, and the DJ Dan Del Santo, along with his friend Joe Nick Patowski, a writer for Texas Monthly. Together they came up with the term during a brainstorming session in 1983 that grew out of a need to describe Del Santo's music (which included a multiplicity of styles from Afrobeat, $R \& B$, and Latin American popular music), his philosophy, and his growing "world conscious-

\footnotetext{
Henry Holt, 1991), ix.

5Jocelyne Guilbault, "Interpreting World Music: a Challenge in Theory and Practice," Popular Music 16, no. 1 (1997): 31-44.

6 As Pierre Bourdieu states: "What is at stake in the struggles about the meaning of the social world is power over the classificatory schemes and systems which are the basis of the representations of groups and therefore of their mobilization and demobilization." Pierre Bourdieu, Distinction: A Social Critique of the Judgement of Taste (Cambridge, Mass.: Harvard University Press, 1984), 479.

7 Kerouac used "world beat" to describe the cosmic, all-encompassing nature of the mambo beat; see Jack Kerouac, On the Road (New York: New American Library, 1957), 235.

8 "Beat," according to Kerouac, connoted "a feeling of being reduced to the bedrock of consciousness"; see Joyce Johnson, "On the Road, Again," Vanity Fair, December 1995, 273. However, there is some dispute as to who originally coined this term; see Barry Miles, Jack Kerouac: King of the Beats (London: Virgin, 1988), 123-24.
} 
ness."9 Within days, Dan Del Santo had the phrase printed on stickers and posters all over the Austin area, promoting his next live show. Later that year, he released his second album on Pleasure Records, entitled World Beat ${ }^{10}$ Soon afterwards, the "world beat" phrase began circulating in the San Francisco area to describe several bands, including the Rhyth-O-Matics, Zulu Spear, the Looters, Special Fun, Mapenzi, and Big City. These groups, like Del Santo, were searching for a catchy, all-inclusive phrase that could unite many musical styles while giving them a fresh tag, free of any built-in prejudgment. The so-called "world beat" movement that resulted attained considerable regional popularity and some national exposure before fading in the mid-1980s. ${ }^{11}$ It should be noted that this movement, as perpetuated by Del Santo and the Bay Area music scene, was more than simply the cross-pollination of various musical styles favouring an infectious beat: the groups also celebrated, in sound, a utopian multicultural social vision, prescribing the breaking down of cultural and economic barriers that separate the world's peoples. ${ }^{12}$ Further, it was also a local-level political movement, as reflected in many of the lyrics that championed the causes of subordinate groups and raised consciousness about social injustices in the Third World.

Dan Del Santo's "world beat" continued to grow in popularity when he released his album Strength to Strength on the British label Earthworks in 1986, to glowing reviews. ${ }^{13}$ His success culminated with the song "In South Africa," which was named "single of the week" in Melody Maker magazine. ${ }^{14}$ Del Santo and his band, the Professors of Pleasure, also garnered rave reviews for their many live shows, including ones from the prestigious WOMAD festival. Despite the success and popularity of his live shows, Del Santo never signed to a major label.

By 1986, Del Santo's term "world beat" began surfacing within the record industry that specialized in international releases, both in the United States and in Great Britain. For instance, the London press release by Earthworks Records not only promoted Del Santo's Strength to Strength album as "world beat," but other new releases as well, including ones from Zimbabwe's Thomas Mapfumo and South Africa's Mahotella Queens. ${ }^{15}$ As the record companies started using

9See Dan Del Santo, press kit (1990).

10Doug Wendt, "North Posse Roundup," Reggae \& African Beat, 1986, 31. Andrew Jones wrongly claims that Del Santo coined the term "world beat" in 1979 in "Small World, Ain't It? WOMAD Makes the Global Village Even Smaller," Option 23 (November-December 1993): 40. Moreover, Goodwin and Gore incorrectly cite the year for the release of Del Santo's album as 1982; see Andrew Goodwin and Joe Gore, "World Beat and the Cultural Imperialism Debate," Socialist Review 20, no. 3 (1990): 65.

$11 \mathrm{Ibid}$. Also in San Francisco in 1983, the DJ Jonathan E., who specialized in playing records of soukous, makossa, soca, samba, and the like, began using the label "world beat" to advertise in a descriptive and succinct way his radio format; see Wendt, "North Posse Roundup," 31.

12For more on how people inscribe their ideal social order in music, see Christopher Small, Music of the Common Tongue: Survival and Celebration in Afro-American Music (New York: Riverrun Press, 1987), chap. 2.

13 See Clive Davidson, "World Beat Goes From Strength to Strength," African Times, 29 September 1986, 1; and Robin Denselow, "World Mix Meltdown," Records Guardian, 29 August 1986, 13.

14See Caroline Sullivan, "Dan Del Santo: In South Africa," Melody Maker, 5 July 1986, 8.

15See Dan Del Santo, press kit (1990). 
the term to categorize their "international" artists, they consequently broadened Del Santo's original definition to reflect whatever "foreign" or "foreigninfluenced" music was in their catalogues. Soon, other small labels began utilizing the "world beat" buzz word (including Rounder, Shanachie, Carthage, Nonesuch/Explorer, and others), particularly once Paul Simon's Graceland album ${ }^{16}$ brought unprecedented attention to international musics in the West. Hence, by 1986 , "world beat" was no longer applicable to just the politicallyconscious, global fusion music exemplified by Del Santo, but was the new term in the American and (to a lesser extent) British record industries to categorize their recordings of various musical styles from around the globe including reggae, jùjú, highlife, and Bulgarian choir music. ${ }^{17}$ Since the 1990s, however, "world beat" has generally fallen out of use (with important exceptions), ${ }^{18}$ reflecting the industry's preference for the term "world music."19

\section{A HISTORY OF THE TERM "WORLD MUSIC"}

The term "world music" or, rather, its German equivalent, Weltmusik, has been in circulation for nearly a century. It was first used by the German musicologist Georg Capellen in 1906 to describe the international influences found in the music of such composers as Debussy and Stravinsky, in particular, the non-Western musics of Indonesia, the Near East, etc. ${ }^{20}$ In more recent times, the term has been used by at least three other groups: European jazz critics since 1963, American ethnomusicologists since 1965, and British record companies since 1987.

It was the German scholar, promoter, producer, and jazz critic JoachimErnst Berendt who began using the term "Weltmusik" around 1963 to label a movement in jazz that incorporated musics from outside America. ${ }^{21}$ Since the early 1960s, Berendt has championed the combination of non-Western musics with jazz. In fact, in 1965, he produced the first "world music" festival, featuring musicians from India, Java, Japan, Africa, and Brazil performing their music in a jazz context. ${ }^{22}$ Berendt defines "world music" as "amalgamating ethnic music from all parts of the world with contemporary jazz."23

16Warner, $92-54474$ (1986).

17 Wendt, "North Posse Roundup," 31. More precisely, "world beat" has come to mean any music that originates in, or borrows substantially from, the musical traditions of regions outside North America or Western Europe but including their "minority" musics, such as zydeco, Cajun, Native American, etc. See Goodwin and Gore, "World Beat," 73; see also Hernandez, "A View From the South," 58; and Sutherland, "Global Rhythms," 5.

18For example, some book and CD-ROM publishers still prefer the term "world beat" as a "catchy" title; see Peter Spencer, World Beat: A Listener's Guide to Contemporary World Music (Chicago: A Cappella Books, 1992); and World Beat: The Sights, Sounds and Video of World Music [CD-ROM] (Redmond, Wash.: Medio Multimedia, 1994).

19One interesting exception is in Canada when, in 1994, the Juno Awards Committee changed the "Best World Beat Recording" category to "Best Global Recording." See the Juno Awards Web site, http://www.juno-awards.ca.

20Joachim-Ernst Berendt, “Über Weltmusik," n.d., 269-74.

21 Berendt, personal communication, 5 June 1996.

22Entitled "Jazz Meets the World," this festival was a five-day event that took place in West Berlin, Germany. Ibid.

23Berendt, The Jazz Book: From Ragtime to Fusion and Beyond, trans. H. and B. Bredigkeit, Dan Morgenstern, and Tim Nevill (Brooklyn, N.Y.: Lawrence Hill Books, 1992), 444. This label did not 
The year that initiated the "world music" movement in jazz, according to Berendt, was 1961, with the release of several albums by John Coltrane: Africa/Brass, ${ }^{24}$ Impressions ${ }^{25}$ (specifically, the tune "India"), and Olé Coltrane $^{26}$ (featuring the tune "Aisha"), which paid homage to African, Indian, and Arabic musics respectively. Coltrane was the first to admit that he did not know much about the music from these places. This probably explains the lack of "authentic" musical references to these traditions; however, what caught on with other musicians was the deep sense of spirituality and exploration found in the music. ${ }^{27}$ Other jazz artists who carried this movement further included Tony Scott, Paul Horn, Paul Winter, John McLaughlin, Collin Walcott, and Don Cherry. In particular, it was the late Don Cherry who put this pan-cultural philosophy consistently into practice. In fact, Cherry often referred to himself as a "world musician" and became the first American jazz artist to play regularly with non-jazz musicians from several continents. ${ }^{28}$ By the 1980 s, groups like Codona and Oregon, and artists such as the saxophonist Charlie Mariano and the trumpeter Jon Hassell, began creating a "world music" in Berendt's fullest sense of the term where one would be hard-pressed to distinguish the Brazilian from the African or Indian; it was, in essence, a "world sound."

The ethnomusicologist Robert Brown is acknowledged as being the first to use the term "world music" in America by the early 1960s. He credits the inspiration for the phrase to his experiences in the late 1950s in the pioneering ethnomusicology program directed by Mantle Hood at the University of California at Los Angeles. ${ }^{29}$ Along with David McAllester, Robert Brown created the World Music Program at Wesleyan University in 1965. The decision to use "world music" reflected Brown's philosophy for the program: for him, "the ideal music department should provide a model of the actual world situation for all human music." ${ }^{30}$ This meant placing Western art music into its legitimate but proportionate place alongside other musical traditions. At Wesleyan, "the world" represented six musical areas: Western art music and jazz, the music of India, Java, Japan and Ghana, and Native American traditions. Although "the world" in this setting became rather selective (due to practical constraints), the term itself was meant to be inclusive, not just as a label for non-Western traditions.

From the 1970s onward, other programs and institutions began sprouting up in the United States and elsewhere using the "world music" phrase, including the Center for World Music in San Francisco (early 1970s), Kent State

begin to appear in the American jazz literature with any regularity until the early 1980 s.

24MCA Records, MCAD-42001.

25MCA Records, MCAD-5887.

26Atlantic Records, 1373-2.

27Berendt, "Jazz and World Music," Jazz Educator's Journal 16, no. 4 (1984): 15.

28 Ibid.

29Robert Brown, "World Music: The Voyager Enigma," in Music in the Dialogue of Cultures: Traditional Music and Cultural Policy, ed. Max Peter Baumann (Wilhelmshaven: Florian Noetzel Verlag, 1991), 366.

30Ibid. 
University's Center for the Study of World Musics (1980), and the World Music Institute (1985), among others, along with a proliferation of "world music" survey courses offered at many universities and colleges. ${ }^{31}$ Often in these settings, however, Brown's original conception of the phrase was lost. No longer was it inclusive of the entire world's musical traditions, but a term used as an alternative for "non-Western" or "ethnic" music. ${ }^{32}$

In the record industry, the term "world music" was first conceived to fulfil a purely functional role. Since the early to mid-1980s, some British independent record companies were licensing and selling records from around the world, especially artists from Africa and the Caribbean. Frustrated by the fact that their "international" product was stuck in the independent record racks along with mostly low-budget punk and rock music (the equivalent of what is now called "Indie" music), they decided to create their own rack space..$^{33}$ On the initiative of Doug Veitch of DiscAfrique, and Roger Armstrong and Ben Mandelson of Globestyle Records, a number of meetings were called, bringing together many of the small independent London-based record companies who released music from around the world. These meetings took place at the London pub, the Empress of Russia, during the summer of 1987. After Veitch's departure in the early stages, a total of twelve labels became involved in the campaign: Triple Earth, World Circuit, Earthworks, WOMAD (since 1989 known as Real World), Rogue, the National Sound Archive, Oval Records, Hannibal Records, Cooking Vinyl, Globestyle, Stern's Records, and Topic Records. ${ }^{34}$ The strategy was to come up with a "marketable" rack space title in which to put their recordings. Some of the possibilities they considered were "tropical music" and "world beat," both of which, the committee decided, privileged the dance-oriented styles such as soukous and zouk, and left out other traditions like Tuvan throat singing. After some debate, a straight show-ofhands vote elected the term "world music." That September and October, a modest campaign got under way. It included the placing of advertisements in some of London's weekly pop music papers, as well as creating a browser card in the record stores' racks with the title "World Music" prominently displayed. ${ }^{35}$ What nobody could have predicted was how the rack space label would take off with the press. Within a matter of months, the label travelled from Britain to the European continent and, by the following June, it garnered a high-profile feature in Newsweek magazine in the United States. ${ }^{36}$ In its issue of 19 May 1990, the music industry trade magazine, Billboard, debuted a biweekly World Music chart listing the top fifteen best-selling albums. ${ }^{37}$ In

$31 \mathrm{Jim}$ Bessman, "World Music Institute Explores Mail-Order: 20 Labels Represented in 1,000-Title Catalog," Billboard, 2 March 1991, 37.

32Carl Rahkonen, "What Is World Music?" MLA Technical Report 24 (1994): 7.

33 Roger Armstrong, personal communication, 15 February 1996.

34 Ibid.

35 The total promotional campaign cost just under $£ 4,000$. Ibid.

36 See Jim Miller, "Pop Takes a Global Spin," Newsweek, 13 June 1988, 72-74. In Canada, the "world music" marketing tag first received national media attention a few months earlier in April of 1988 in Maclean's; see Nicholas Jennings, "Expeditions to Pop's Global Village," Maclean's, 25 April 1988, 57-58.

37 See "Billboard Debuts World Music Album Chart," Billboard, 19 May 1990, 5. 
1991, the recording academy created a new Grammy category, "Best World Music Album," further legitimizing the term within the industry. ${ }^{38}$

The British record industry's choice of the term "world music" was an intriguing coincidence, for, as I have outlined, the phrase already had widespread circulation within several small circles. ${ }^{39}$ In addition, it is because of the adoption of the term as a musical category by the music industry that its definition has competed with, and in many cases, supplanted, the already existing definitions found within these other circles.

What happened in France is a case in point. As early as 1984, the influential monthly magazine, Actuel, and its broadcasting subsidiary, Radio Nova, were using the term "sono mondiale" [world sound] for the music of Parisian-based African and Antillean artists. ${ }^{40}$ The Zairean keyboardist Ray Lema, and JeanFrançois Bizot, the director of Actuel, conceived the "sono mondiale" concept as a sound that could be danced to by both blacks and whites. The major labels in France (who act as subsidiaries of British and American conglomerates), were not interested in this new sound and so it was released only on small, independent French labels. "Sono mondiale" became a term that both reflected this new music made by Parisian immigrants, and "offered a direct challenge to a French music scene dominated by British and American multinationals." 41 Ironically, the British record companies soon recognized the marketability of the new sounds from Paris, and began signing Parisian-based artists such as Kanda Bongo Man, Papa Wemba, and others, and in turn, "encouraged" the French industry to adopt their British term "world music," to categorize them. ${ }^{42}$ Today in France, this music is categorized as "world music."43

Since 1986, the term "world beat" was the favoured marketing label in the United States, but once the "world music" hype in Europe caught the attention of the American media, it, too, became used. By 1988, the two terms, one of British origin, the other American, were both being applied by the American

38 Karen O'Connor, “Grammy Adds 3 Categories: World Music Among New Awards," Billboard, 8 June $1991,87$.

$39 \mathrm{Had}$ the term not already been a label among the jazz media, as part of the vocabulary and philosophy of composers such as Karlheinz Stockhausen (who was attempting to create a "world music" by 1966 in Telemusik) as well as a term in ethnomusicological circles, it is unclear if "world music" would have gained currency as quickly and widely as it did.

40 Chris Stapleton, "Paris, Africa," in Rhythms of the World, ed. Francis Hanly and Tim May (London: BBC Books, 1989), 21.

41 Ibid.

42Roger Armstrong indicated that there was reluctance in the French industry towards adopting this term for what the French were calling "their" music (personal communication, 15 February 1996).

43Elsewhere in Europe, Spain adopted the English "world music" as well as the Spanish "musicas del mundo"; see Brian Eno, “¿Por Qué World Music?" Ghaita, March-April 1994, 6. Germany, which originally favoured "ethno-pop" in the mid-1980s to describe non-Western-based popular music, has since adopted the term "Weltbeat"; see Peter Niklas Wilson, "Zwischen 'Ethno-Pop' und 'Weltmusik': eurozentrische Grundstrukturen im Umgang mit außereuropäischer Musik," Neue Zeitschrift für Musik 148, no. 5 (1987): 5 . A connection to the American use of the term is possible but it more readily can be traced to the German music magazine Weltbeat and a Nordwestdeutscher Rundfunk double compilation album of the same name. In Britain, the world beat tag is largely used as an Americanism; Armstrong (personal communication, 15 February 1996). 
music industry to describe the same loose collection of musical genres ${ }^{44}$ and, therefore, now tend to be used interchangeably. ${ }^{45}$

There is sometimes a tendency among scholars to presume that, because a label exists, the phenomenon signified by the label also has a full, discrete, and objective existence. As demonstrated by the histories of the terms "world music" and "world beat," the phenomena they attempt to label are far from uniform. In explaining this process, one can look at Steven Feld's schismogenesis concept. Feld describes the process of a sound being split from its source through commodification; the sound then becomes subject to transformation, and this, in turn, further precipitates distorted interpretations of meaning and value..$^{46}$ Although Feld relates this process to the interpretation of sound recordings, it can also be applied to a word or phrase itself and its meaning in different contexts. As we notice in the cases just outlined, once a term becomes separated from its source (or from its original contextualized use), it becomes subject to reinterpretation and rearticulation.

Schismogenesis highlights the strange irony in the mutation of some of the original usages of these labels to reflect the politics of their subscribers. All of the original proponents of these terms, the German scholar Joachim-Ernst Berendt, the American ethnomusicologist Robert Brown, and the musician Dan Del Santo, independently came up with their terms to reflect a similar musical and philosophical position: music as "world music" or "world beat" could be viewed homologously as a model for how people on our diverse planet can live together. ${ }^{47}$ Moreover, it reflected the emergence of a new kind of musicianship,

44 It should be noted that "world beat" retains some of its dance music/fusion connotations in some circles. One explanation as to why there is a lingering preference in the United States for the term "world beat" rather than the more expansive term "world music," deals with the connotation of the word "beat" which "tacitly acknowledges the primacy of rhythm, so essential to African musical aesthetics." Hernandez, "A View From the South," 58.

45Evidence that journalists, music scholars, and industry people have been using the terms interchangeably include: Brooke Wentz, "It's a Global Village Out There," DownBeat 58, no. 4 (1991): 22; Ken Terry, "NMS Panel Explores World Beat Music's Potential," Billboard, 5 August 1989, 30; Jennings, "Expeditions," 57; Brian Cullman, "The Global Beat," Vogue 179, no. 5 (1989): 192, 196; George Plasketes, "Cross-Cultural Sessions: World Music Missionaries in American Popular Music," Studies in Popular Culture 18, no. 1 (1995): 49; Goodwin and Gore, "World Beat," 63; Veit Erlmann, "The Politics and Aesthetics of Transnational Music," The World of Music 35, no. 2 (1993): 3, 9; World Beat [CD-ROM]; Garofalo, "Whose World?" 27; Glanvill, "World Music Mining"; McLane, "The Global Beat," 663; Spencer, World Beat; John Collins, West African Pop Roots (Philadelphia: Temple University Press, 1992), 328; John Lannert, "Notas," Billboard, 16 November 1991, 68; and Hernandez, "A View From the South," 48. To illustrate just how complex the interchange of these two terms is, as early as 1983, Del Santo's "world beat" music was sometimes referred to as "world music" in America (see Byron Wheeler, "Still Rockin': The World Beat According to Professor Del Santo," Third Coast, May 1983, 42), while Earthworks Records, one of the original labels in 1987 to market their material as "world music" in the United Kingdom, was marketing their catalogue as "world beat" the year before (see Del Santo, press kit). Therefore, by making the geographical distinction that "world beat" is used in the United States and "world music" in Europe, the ethnomusicologist Hernandez has oversimplified this phenomenon; see Hernandez, "A View From the South," 48.

46Feld, "From Schizophonia," 263.

47 See Berendt, The Jazz Book, 55; Brown, "World Music," 374; Wheeler, "Still Rockin.”" 
a new kind of human consciousness, that only comes from stepping beyond one's own culture and drawing upon other cultures. ${ }^{48}$ Ironically, the terms that originally connoted "inclusion," and encouraged the breaking down of musical and cultural barriers through this new "consciousness," were co-opted and turned into another musical/cultural/linguistic barrier, one that articulates the musical "other." 49 There are a number of critiques of this shift in labelling; I will outline three..$^{50}$

Firstly, the criteria used by record industry insiders to categorize artists as "world music," or the "other," border on the arbitrary or are based on language and geography and not on musical style. ${ }^{51}$ One such example is found in the case of pop star, Céline Dion, whose French-language albums are shelved in "world music" sections of many record stores, including those in her home country of Canada. This despite the fact that the only "exotic" or "foreign" elements found in her music that distinguish it from the Anglo-American pop mainstream is that some lyrics are in French. Moreover, this type of categorization is not unique to North America, for, even in Japan, Chinese rock groups such as Hei Bao are categorized as "world music," while British or American rock groups are not. These examples illustrate that the industry has created a musical category where musical sound may be an irrelevant criterion.

Secondly, the "world beat/world music" classification often creates a musical and artistic ghetto by marginalizing these artists apart from the mainstream media, particularly with regard to prime air-time on radio and television, advertising in trade magazines, etc. By virtue of this classification, "world music" artists find it more difficult now than years ago to break into mainstream North American radio and music television, a fact that many industry insiders acknowledge..$^{52}$ In this way, being labelled as "other" or "exotic" or "world music" is not only exclusionary, but implies notions of inferiority as well. Hence, such a classification becomes legitimized cultural, musical, and linguistic segregation. ${ }^{53}$ Further, any movement from out of this marginalized space into the mainstream or "our" space is largely made impossible by the ones controlling this distinction..$^{54}$

48 See Brown, "World Music," 367; and Berendt, The Jazz Book, 44.

49 As Carl Rahkonen states in defining "world music": "It is simply not our music, it is their music, music that belongs to someone else." Rahkonen, "What is World Music?," 1.

50For a more complete critique of these classifications see Feld, "From Schizophonia;" idem, "Notes On World Beat"; Grenier and Guilbault, “'Authority' Revisited”; and Mitchell, "World Music."

51 Simon Hopkins, "World Music: Songs from the Global City," liner notes in The Virgin Directory of World Music, compact disc.

52Emmanuel Legrand, "Paris Meet Maps Out Course of World Music: Anglo Dominance Seen as Limiting Industry's Scope," Billboard, 11 May 1991, 68.

53 Angélique Kidjo, a singer from Benin, points out the danger of being categorized as "world music" as being "left out of the mainstream, because this music is given the same weight in the market that the Third World is given on the global economic chessboard." In Laurent Aubert, "The World Dances to a New Beat: An Invitation to the 'Great Pluralistic Jamboree,"'World Press Review 39, no. 1 (1992): 25.

54 The press agent, Larry Gold, insists that the American public cannot deal with "world music" on an artist-by-artist basis, and so umbrella terms like "world beat" must continue to be used; see Kevin Zimmerman, "Sing and the Whole World Sings with You-Now in Any Language," Variety, 22 March 1989, 102. 
Thirdly, the emergence of new barriers recasts such questions as "Who is 'us' and who is 'them'?" Or, rather, who are the ones making these "us" and "them" distinctions? As the terms are used today, it is largely the music industry, from record labels and stores, A\&R representatives, and producers, more than the artists themselves, that control this distinction. In a world of jet travel, immigration and emigration, tourism, and multicultural visions of societies, the formation of cosmopolitan metropolitan areas, and an emerging globalization, ${ }^{55}$ the "them" or "others" of the planet, have become impossible to identify. ${ }^{56}$ And "world music," functioning as a "legitimate" musical classification, fails to properly acknowledge that strangeness, familiarity, and "otherness" are not fixed but shifting, dynamic categories relative to individual perspectives. Further, the identification of any given cultural category as homogenous is a misnomer, for identities are as much constructed through conflict and opposition as they are from similarity and order..$^{57}$

Anthropologists have undertaken this very re-examination of the standard "us" and "them" dichotomies. Historically, the "other" had been developed within a colonial framework and equated with people living elsewhere. The recent trend has been the redefinition of the "other," not as a self-enclosed object, but, rather, "as an object that can be defined only in its relation to the researcher." 58 Applying this conception to the world music consumer means that a recording would be designated "world music" relative not to specific languages, countries, or regions, as dictated by the industry, but to each individual listener. ${ }^{59}$ Instead, the recent application of the term reifies a Western-centred perspective.

In all fairness, the music industry's adoption of a marketing label for musics outside the Western mainstream has created a space for artists and musical traditions where there previously was none. In many ways, the media hype that accompanied the "world music" boom of the late 1980s has helped to raise the profile of artists who would otherwise have had no way of entering the Western market. However, in a time when distinctions between "us" and "them," "centre" and "periphery," and "First" and "Third" World are fundamentally being challenged, the neo-colonialist attitude, exemplified by these musical classifications as dictated by the music industry, is in dire need of re-evaluation. For it seems that just when the industry has finally settled on a label, the way it is applied seems sorely misrepresentative of the many musical, political, and cultural boundaries that are being renegotiated daily in transactions which

55 Johann Arnason defines globalization as "the crystallization of the entire world as a single place and as the mergence of a global-human condition." See Johann Arnason, "Nationalism, Globalization, and Modernity," in Global Culture: Nationalism, Globalization and Modernity: A Theory, Culture and Society Special Issue, ed. Mike Featherstone (Newbury Park: Sage, 1990), 220.

56Lawrence Grossberg, "On the Road with Three Ethnographers," Cultural Studies 3, no. 2 (1989): 23-26.

57 See Michelle Rosaldo, "The Use and Abuse of Anthropology: Reflections on Feminism and Cross-Cultural Understanding," Signs 5, no. 3 (1980): 389-417.

58 Grenier and Guilbault, "“Authority' Revisited," 385.

59 Of course, this would render such a designation useless from a marketing and music industry standpoint. 
resemble the original inspiration for the creation of the terms "world music" and "world beat" in the first place.

\begin{abstract}
This article traces the origins and uses of the musical classifications "world music" and "world beat." The term "world beat" was first used by the musician and DJ Dan Del Santo in 1983 for his syncretic hybrids of American R\&B, Afrobeat, and Latin popular styles. In contrast, the term "world music" was coined independently by at least three different groups: European jazz critics (ca. 1963), American ethnomusicologists (1965), and British record companies (1987). Applications range from the musical fusions between jazz and non-Western musics to a marketing category used to sell almost any music outside the Western mainstream.
\end{abstract}

